\title{
Genetic Polymorphism in FecB Gene in Iraqi Sheep Breeds Using RFLP-PCR Technique
}

\author{
Yousif M. S. Al-Barzinji1 ${ }^{1}$ and Galawezh U. Othman ${ }^{2}$ \\ ${ }^{1 .}$ Department of Animal Resource, College of Agriculture, University of Salahaddin, Erbil, Iraq \\ 2. Department of Biology, College of Education, University of Salahaddin, Erbil, Iraq
}

\begin{abstract}
This study was conducted to identify polymorphism in Booroola gene (FecB) in five Iraqi sheep breeds (Hamdani, Karadi, Arabi, Naeimi and Awassi). About fifty mature ewes (Ten for each breed used as pooled samples) were genotype for the Booroola (BMPRIB) receptor. The polymerase chain reaction (PCR) was used for amplification of a fragment with $140 \mathrm{bp}$ at this locus. For genotyping of individuals at Booroola locus, the resulted amplified fragments were digested using AvalI restriction enzyme. AvalI restriction enzyme was used to detect possible mutation $(G \mid G A C C)$. The results showed no differences in the band patterns of digested products only the wild type alleles (Fec++) were detected and all breeds for this locus were monomorphism. Considering the phenotypic records in these breeds, the result revealed that the genetic factor responsible for litter size is not related to report of Booroola major gene and research should continue to search for other major genes ( such as FecH, FecX and FecG) in these sheep breeds.
\end{abstract}

Key words: Iraqi sheep breeds, Booroola gene, RFLP_PCR.

\section{Introduction}

Indigenous farm animal breeds are valuable gene pools for adaptive and economic traits, providing diversified genetic pool, which can help meeting future challenges. The earliest evidence about sheep domestication seems to be found in the areas of Iraq, Iran and the Taurus mountains of Turkey [1]. The sheep population of Iraq in 1999 was about six-million [2]. Most of this population (99.8\%) is owned by the private sector and is distributed all over the country. The native breeds include the Karadi (Kurdi, Hamdani, Jaff and Dzaie) 20\%, Awassi (Naami and Shefali) 58.2\% and Arabi sheep 21.8\%. These are all fat-tailed, carpet-wool production with some potential to produce milk. Although these breeds are characterized by slow growth, low fertility and low milk production, their ability to survive and reproduce under condition of drought and extreme climate fluctuations is remarkable [3]. It has been discussed that ovulation rate and the subsequent litter size are the main factors for improving reproductive rate in sheep [4] .Many studies have indicated that the ovulation rate and litter size can be genetically regulated by a set of different genes, collectively named as fecundity $(\mathrm{Fec})$ genes [5]. The bone morphogenetic protein receptor type IB (BMPRIB) or activin-like kinase 6 or FecB on chromosome 6 [6], identified in the Australian Booroola Merino strain [7], is the first major gene to be described that affects ovulation rate and prolificacy in sheep. Molecular genetics can overcome these limitation offering new opportunities to the improvement of reproductive traits, as it supplies tools to analyze genetic variability directly at the DNA level with the possibility of detecting the individual genes influencing the reproductive characteristics. The identification of polymorphism and DNA markers associated with reproductive traits can lead to genetic improvement through the implementation of marker assisted selection (MAS) by breeder to increase litter size and reproduction efficiency [1].

The main objective of the present research was to apply PCR-RFLP technique for determining BMPR-IB gene polymorphism in five Iraqi sheep breeds.

\subsection{Sampling and DNA extraction}

\section{Materials and Methods}

A total of 50 adult ewes from five breeds representing Hamdani ( $n=10$ from two locations, 5 samples for each location), Karadi $(n=10)$, Awassi $(n=10)$, Naeimi $(n=10)$ and Arabi $(n=10)$. Each 10 samples for each breed mixed together made as one sample (except Hamdani made two sample 5 from each location). Blood sample from each ewe was collected from jugular vein into $10 \mathrm{~mL}$ vacationer tubes containing the anticoagulant, Ethylenediaminetetra-Acetic Acid (EDTA).

\subsection{DNA isolation}

Genomic DNA was extracted from blood using GFX Kit (produced by Amershan Bioscinces) and stored at $-20^{\circ} \mathrm{C}$ till used in assay. The purity and concentration of DNA samples was estimated using UV-visible range spectrophotometer. DNA concentration was adjusted to $50 \mathrm{ng} / \mu \mathrm{l}$ before PCR amplification. All the DNA 
samples had the 260/280 OD ratios in the range of 1.8 to 2, indicating high purity. DNA was also examined by loading samples on $1 \%$ agarose gel and visualizing the band under gel documentation system.

\subsection{Primer synthesis and PCR-RFLP reactions}

The Booroola (BMPR-IB) gene is located on ovine chromosome 6 with a coding sequence of $1509 \mathrm{bp}$, which could be divided into 10 exons and coded 502 amino acids [6 and 8]. It was designed a pair of specific primers based on the A746G mutation of ovine BMPR-IB gene, and the amplification product size was $140 \mathrm{bp}$. The primer sequences were as follows:

Forward:5'-GTCGCTATGGGGAAGTTTGGATG-3'. Reverse:5'-CAAGATGTTTTCATGCCTCATCAACACGGTC-3'.

The polymerase chain reactions (PCRs) were carried out in a volume of $25 \mu 1$, containing approximately $10 \times \mathrm{PCR}$ buffer [50 mmol/l KCl, $10 \mathrm{mmol} / \mathrm{l} \mathrm{Tris-HCl}(\mathrm{pH} 8.0), 0.1 \%$ Triton X-100] $2.5 \mu 1,1.5 \mathrm{mmol} / 1 \mathrm{MgCl} 2$, $250 \mu \mathrm{mol} / 1$ each deoxynucleoside triphosphate (dNTP), $50 \mathrm{ng}$ each primer, $100 \mathrm{ng}$ ovine genomic DNA, and 1.5U Taq DNA polymerase (SABC, Beijing, China). PCR conditions were as follows: denaturation at $94{ }^{\circ} \mathrm{C}$ for $5 \mathrm{~min}$, followed by 35 cycles of denaturation at $94^{\circ} \mathrm{C}$ for $30 \mathrm{~s}$, annealing at $60{ }^{\circ} \mathrm{C}$ for $30 \mathrm{~s}$, extension at $72^{\circ} \mathrm{C}$ for $30 \mathrm{~s}$, with a final extension at $72^{\circ} \mathrm{C}$ for $5 \mathrm{~min}$. The resulting products were kept at $4{ }^{\circ} \mathrm{C}$. The PCR products were digested with AvalI (Digestion reaction contain $5 \mu \mathrm{L}$ of PCR product, $5 \mathrm{U}$ appropriate enzyme, $2 \mu \mathrm{L}$ buffer $10 \times$ ) in $20 \mu \mathrm{L}$ final volume incubated for $3-6 \mathrm{~h}$ at $37^{\circ} \mathrm{C}$. The resulting products were separated by electrophoresis on a $3 \%$ agarose gel and visualized with Ethidium bromide under gel documentation system. All laboratory work was done in the Advance parasitology laboratory at the Department of Biology, College of Education, University of Salahaddin, Erbil, Iraq, during April, 2012 till June, 2012.

\subsection{Genotype analysis}

The PCR product of the $F e c B$ gene produced a 140 bp band. After digestion with AvalI (Fermentas), the $F e c B$ gene homozygous carriers should produce a 110 bp band $(F c e B B)$, the non-carrier should produce a 140 bp band $(\mathrm{Fec++})$, whereas heterozygote should produce both 110 and $140 \mathrm{bp}$ bands $(\mathrm{FecB}+$ ).

\section{Results And Discussion}

Results of the FecB gene PCR products after AvaII digestion can be seen on fig.1. Thus this PCRRFLP technique can be used to detect and genotype $F e c B$ gene clearly. It is clear from the AvaII RFLP pattern represented on the fig.1, that digestion of the $F e c B$ gene 140 base pair with AvalI restriction enzyme resulted in non carrier (++) 140 bp band (wild type) in (Hamdani, Karadi, Awassi, Naeimi and Arabi) Iraqi sheep breeds. These results are in agreement with reports in Mulpura sheep [9], Rahmani, Ossimi, Awassi and Barki [10], Shal sheep [11], Sangsari sheep [12], Hamdani sheep [13], Baluchi sheep [14], Egyptian Sheep [15], Najdi and Naeimi sheep [16] and Dalagh sheep [17]. However, results contrast other reports in Booroola Merino [18], Garole [19],Hu and Han sheep [20], Garole sheep [9], Hu sheep and Chinese Merino prolific meat strain [21], Zel sheep [1]. In our experiment, PCR-RFLP approach was used to detect the genotype based on the method described by [6] and [19]. RFLP has a good repeatability and stability, but its results were affected by several factors, such as enzymes from different companies, time of digestion and volume of electrophoresis and concentration of gel. Several of these factors were compared by adding various concentrations of ingredients to select the optimal reaction conditions to maintain repeatability and veracity. Detections with illegible results were repeated until the genotyping was clear.

\section{Conclusion}

In the present study the results of PCR showed the same band (140 bp) pattern in all five Iraqi sheep breeds, implying no mutation in $F e c B$ locus in our five ewe breeds. Regarding the records of twinning in Iraqi sheep breeds it is concluded that the genetics factor controlling litter size is not related to the mutation, which is reported in Booroola major gene. It may be concluded that litter size in Iraqi sheep breeds may affected some other major genes (such as FecX, FecH and BMP-15) or may be polygenic quantitative trait. Further research is recommended to investigate these hypotheses. 


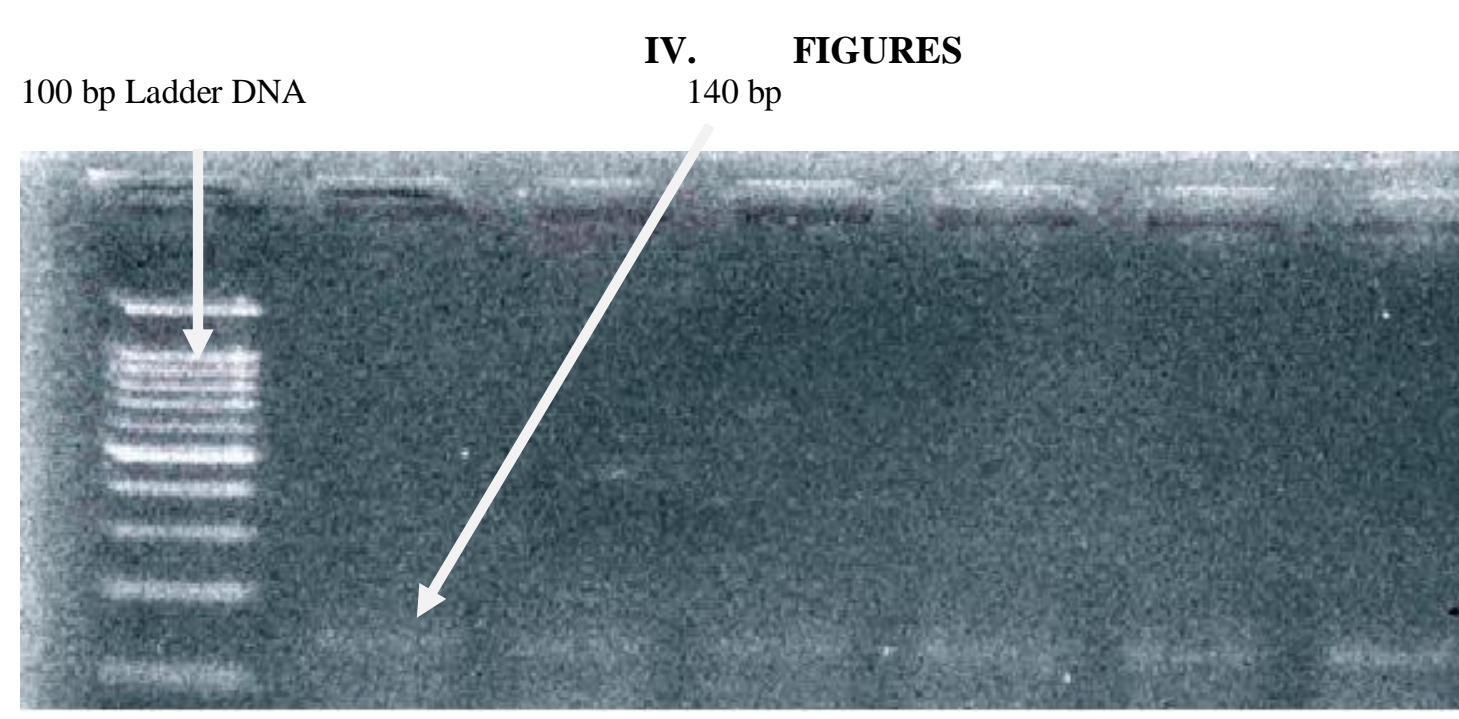

\section{Hamdani1 Hamdani2 Karadi Awassi Naeimi Arabi}

Fig. 1: PCR-RFLP analysis on agarose gel electrophoresis of FecB gene in five Iraqi sheep breeds.

\section{References}

[1] R. Asadpour, R. Jafari-Joozani, S. Alijani, H. Mahmodi, Detection of polymorphism in booroola gene (FecB) and Its association with litter size in Zel sheep breed in Iran. Slovak J. Anim. Sci., 45, (2), 2012, 63-66.

[2] FAO (Food and Agriculture Organization), Quarterly Bulletin of Statistics, Vol. 1. FAO, Rome, Italy, 2000.

[3] A.A. Al-Rawi, A.H. Al-Haboby, M.H. Al-Salman. Small Ruminant Breeding and Reproductive Physiology Research and Technology Transfer in Iraq ( W. Mourrani and N. Haddad, ed.). ICARDA-West Asia Regional Program, Amman, Jourdan , 1996.

[4] G.E. Bradford, Genetic control of litter size in sheep. J. Reprod. Fertil. Suppl . 15, 1972, 23-41

[5] G.H. Davis, G. Montgomery, A. Allison, R. Kelly, R. Braya, Segregation of major gene influencing fecundity in progeny of booroola sheep. New Zealand Journal of Agricultural Research, 25, 1982, 525-529.

[6] C.J. Souza, C. MacDougall, B.K. Campbell, A.S. McNeilly, D.T. Baird, The booroola (FecB) phenotype is associated with a mutation in the bone morphogenetic receptor type 1 B (BMPR1B) gene. J. Endocrinol.169,2001, R1-R6.

[7] L. R. Piper, B. M. Bindon, G. H. Davis, The single gene inheritance of the high litter size of the booroola merino. In: Land, R.B., Robinson, D.W. (Eds.), Genetics of Reproduction in Sheep. Butterworths, London, 1985, 115-125.

[8] P. Mulsant, F. Lecerf, S. Fabre, L. Schibler, P. Monget, I. Lanneluc, C. isselet, J. Riquet, D. Monniaux, I. Callebaut, E. Cribiu, J. Thimonier, J. Teyssier, L. Bodin, Y. Cognie, N. Chitour, J.M. Elsen, Mutation in the bone morphogenetic protein receptor-IB is associated with increased ovulation rate in booroola ewes. Proc. Natl. Acad. Sci. USA. 98, 2001,5104-5109.

[9] S. Kumar, A.P. Kolte, A.K. Mishra, A.L. Arora, V.K. Singh, Identification of the FecB mutation in Garole $\times$ Malpura sheep and its effect on litter size. Small Rumin. Res. 64 , 2006, 305-310.

[10] A. El-Hanafy, M.A. El-Saadani, Fingerprinting of FecB gene in five Egyptian sheep breeds. Biotechnology in Animal Husbandry. 25 (3-4), 2009, 205-212.

[11] M. Ghaffari, Detection of polymorphism in BMPR-IB gene associated with twining in Shal sheep using PCR-RFLP method. Int. J. Agric. Biol. 11: (1), 2009.

[12] M. M. Kasiriyan, H. Hafezeyan, H. Sayahzadeh, R. Jamshidi, Genetic polymorphism FecB and BMP15 genes and its association with litter size in Sangsari sheep breed of Iran. J. Animal anf Veterinary Advances. 8 (5), 2009, 1025-1031.

[13] Y. M. S. Al-Barzinji, Polymorphism in booroola (FecB) gene associated with litter size in Hamdani sheep. J. Dohuk Univ. Vol.13 (1), 2010, 413-417.

[14] F. Moradband, G. Rahimi, M. Gholizadeh, Association of polymorphisms in fecundity genes of GDF9, BMP15 and BMP15-1B with litter size in Iranian Baluchi sheep. Asian-Aust. J. Anim. Sci., 24 (9), 2011, 1179-1183.

[15] I. Abulyazid, M. S. Abdalla, , H.M. Sharada, W.F. Hassanin, Prolificacy detection in Egyptian sheep using RFLP-Specific PCR. Egypt. Acad. J. Biolog. Sci., 3(1), 2011, 1-4.

[16] M.A. Abouheif, A. N. Al-Owaimer, T.M. Shafey, M.A. AlShaikh, Polymorphism of booroola FecB gene in prolific individual from Najdi and Naeimi sheep breed of Saudi Arabia. J. Animal and Veterinary Advances, 10(10), 2011, 1262-1264.

[17] R.K. Nejhad, A.K. Ahmadi, Genetic polymorphism in GDF9 and FecB in Dalagh sheep breed of Iran. J. Animal and Veterinary Advances, 11(6), 2012, 766-768.

[18] X.Y.W. Wilson, J.L. Juengel, I.K. Ross, J.M. Lumsden, E.A. Lord, K.G. Dodds, G.A. Walling, J.C. McEwan, A.R. O’Connell, K.P. McNatty, G.W. Montgomery, Highly prolific booroola sheep have a mutation in the intracellular kinase domain of bone morphogenetic protein IB receptor (ALK-6) that is expressed in both oocytes and granulosa cells. Biol. Reprod. 64, 2001, 12251235 .

[19] G.H. Davis, S.M. Galloway, I.K. Ross, S.M. Gregan, J. Ward, B.V. Nimbkar, P.M. Ghalsasi, C. Nimbkar, G.D. Gray, Subandriyo, I. Inounu, B. Tiesnamurti, E. Martyniuk, E. Eythorsdottir, P. Mulsant, F. Lecerf, J.P. Hanrahan, G.C. Bradford, T. Wilson, DNA test in prolific sheep from eight countries provide new evidence on origin of the booroola (FecB) mutation. Biol. Reprod. 66, 2002, 1869-1874.

[20] G.H. Davis, L. Balakrishnan, I.K. Ross, T. Wilson, S.M. Galloway, B.M. Lumsden, J.P. Hanrahan, M. Mullen, X.Z. Mao, G.L. Wang, Z.S. Zhao, Y.Q. Zeng,J.J. Robinson, A.P. Mavrogenis, C. Papachristoforou, C. Peter, R. Baumung, P. Cardyn, I. Boujenane, N.E. Cockett, E. Eythorsdottir, J.J. Arranz, D.R. Notter, Investigation of the booroola (FecB) and inverdale (FecXI) mutations in 21 prolific breeds and strains of sheep sampled in 13 countries. Anim. Reprod. Sci. 92, 2006, 87-96.

[21] F. Guan, L. Shou-ren, G-Q. Shi, 2007.L-G. Yang, Polymorphism of FecB gene in Nine sheep breeds or strains and its effects on litter size, lamb growth and development. Anim. Reprod. Sci. 99, 2007, 44-52. 